\title{
Purification and characterisation of a metallopeptidase of Candida albicans
}

\author{
B. EL MOUDNI, MARIE-HÉLĖNE RODIER, CHRISTINE BARRAULT, M. GHAZALI \\ and J. L. JACQUEMIN
}

Laboratoire de Parasitologie et Mycologie Médicales, Centre Hospitalier Universitaire La Milétrie, BP 577, 86021 Poitiers Cedex, France

\begin{abstract}
Summary. A novel aminopeptidase was purified by high performance liquid chromatography from a cytosoluble $100000 \mathrm{~g}$ extract of Candida albicans on the basis of its ability to cleave Larginine 7-amino-4-methylcoumarin. The purification factor was 36 and the yield was $20 \%$. The native enzyme had a mol. wt of $52 \mathrm{kDa}$ as demonstrated by SDS-PAGE in the presence or absence of reducing conditions and exhibited an iso-electric point of 4.3. The aminopeptidase showed optimum activity at $\mathrm{pH} 7 \cdot 2$, a Michaelis constant of $c .50 \mu \mathrm{M}$ and a $\mathrm{V}_{\max }$ at $19 \mathrm{~mm}$ AMC released $/ \mathrm{min} / \mathrm{mg}$ of protein for L-Arg-AMC. This enzyme was shown to cleave at low affinity L-leucine-7-amino-4-methylcoumarin as demonstrated by the spectrofluorimetric method. The enzyme was strongly inhibited by specific metallo-enzyme inhibitors-EDTA and $o$-phenanthroline. Furthermore, there is evidence that a similar or identical enzyme occurs in other $C$. albicans clinical isolates and other Candida spp.
\end{abstract}

\section{Introduction}

There is accumulating evidence of the involvement of yeast peptidases in host-micro-organism interactions, including digestion of exogenous proteins for nutritive purposes, invasion of host cells and tissues, and inactivation of host proteins that are detrimental to yeast survival. ${ }^{1,2}$

Candida albicans is a dimorphic yeast that colonises mucosal surfaces of the gastrointestinal tract, genitourinary tract and the oral cavity. This organism has become an important pathogen in immunocompromised patients as well as in patients with various other underlying conditions that abrogate or impair immunity. Many peptidase activities have been detected in this yeast. Some of these enzymes have been purified and characterised. ${ }^{3-9}$ However, the biological functions of these peptidases are not known. An extracellular proteinase (SAP) was purified from the culture media of various strains of C. albicans by Rüchel, ${ }^{4}$ and was characterised as an aspartyl proteinase with broad substrate specificity. This glycoprotein had an $M_{r}$ of $42-45 \mathrm{kDa}$ and an activity in the $\mathrm{pH}$ range $2-7 .^{2.4,10}$ An intracellular proteinase with optimum activity at $\mathrm{pH} 6 \cdot 6^{9}$ and three cytoplasmic enzymes - a metal-ion-dependent aminopeptidase, ${ }^{5} \mathrm{a}$ dipeptidase $^{5}$ and a carboxypeptidase ${ }^{11}$ - have been

Received 7 Feb. 1995; revised version accepted 8 March 1995. identified. Recently, two serine proteinases were detected from cytoplasmic extracts of $C$. albicans by SDS-PAGE with gels containing gelatin as proteinase substrate. ${ }^{12}$

In this investigation, a novel cytoplasmic $C$. albicans aminopeptidase activity was identified by means of highly sensitive substrates with methylcoumarin groups. The purification and characterisation of a $52-\mathrm{kDa}$ metallopeptidase from cell-free extracts of C. albicans are described. C. albicans clinical isolates from urine, vagina and the mouth and other Candida species were examined for similar metallopeptidases.

\section{Materials and methods}

\section{Materials}

Substrates for peptidase including 7-amino-4methylcoumarin derivatives (AMC), peptidase inhibitors-DTT, dithiothreitol; E64, transepoxysuccinyl-L-leucylamido(4-guanidino)butane; NEM, $N$-ethylmaleimide; phosphoramidon, $N$ - $(\alpha-$ rhamnopyranosyloxyhydroxyphosphinyl)-L-leucyl-Ltryptophan; PMSF, phenylmethylsulphonyl fluoride; TLCK, $N$ - $\alpha$-p-tosyl-L-lysine chloromethyl ketoneand pre-stained mol. wt markers were purchased from Sigma. The TSK-G3000 SW $\times \mathrm{L}$ column was from Toyo Soda (Tokyo, Japan); Fractogel EMD-TMAE 650 columns were obtained from Merck (Clevenot, 
France); Mono P HR $5 \times 20$ columns and Polybuffer 74 were from Pharmacia (Uppsala, Sweden).

\section{Cultivation method and yeast extracts}

C. albicans strain 2091 was obtained from The Pasteur Institute (Paris, France). Nine clinical Candida isolates were used: three $C$. albicans isolates from urine, vagina and the mouth, and single isolates of C. tropicalis, C. glabrata, C. parapsilosis, C. krusei, C. guilliermondi and C. pseudotropicalis. All strains were grown for $48 \mathrm{~h}$ on Sabouraud's dextrose agar slants at $37^{\circ} \mathrm{C}$.

The cells were harvested in $10 \mathrm{~mm}$ Tris- $\mathrm{HCl}$ buffer, $\mathrm{pH} 7.2$, containing $150 \mathrm{~mm} \mathrm{NaCl}$ (TBS), washed three times by centrifugation and suspended to a final concentration of $10^{9}$ cells $/ \mathrm{ml}$ in the same buffer. The cells were disrupted for $10 \mathrm{~min}$ in a cell homogeniser MSK (B. Braun, Melsungen, Germany) with glass beads $(0.45-0.55 \mathrm{~mm})$ with cooling under $\mathrm{CO}_{2}$.

Disrupted yeasts were centrifuged at $100000 \mathrm{~g}$ for $30 \mathrm{~min}$ at $4^{\circ} \mathrm{C}$, to remove glass beads, unbroken cells and cell debris. The supernatant fluid was taken as the cytoplasmic yeast extract and used for the assays or stored at $-80^{\circ} \mathrm{C}$ until required. Protein concentration was determined as described by Bradford, ${ }^{13}$ with bovine serum albumin as a standard. All crude extracts used had the same protein concentration.

\section{Enzyme purification}

All the procedures were performed by high performance liquid chromatography (HPLC, Laboratoires Merck Clevenot, France).

For ion-exchange chromatography, $1 \mathrm{ml}$ of yeast extract was applied to a Fractogel EMD-TMAE 650 column $150 \times 10$, previously equilibrated with $25 \mathrm{~mm}$ Tris- $\mathrm{HCl}, \mathrm{pH} 7 \cdot 4$. A linear gradient was performed in the same buffer from 0 to $0.5 \mathrm{M} \mathrm{NaCl}$ in 30 min with a flow rate of $30 \mathrm{ml} / \mathrm{h}$. Samples of each $0.5-\mathrm{ml}$ fraction were tested with $\mathrm{L}$-arginine-AMC (L-Arg-AMC).

For gel filtration, the active fractions from the ionexchange column were pooled and concentrated by ultra-filtration with Centricon 10 (Amicon), and submitted to a TSK G3000 SW $\times \mathrm{L}$ column $30 \times 7 \cdot 8$, equilibrated with $25 \mathrm{~mm}$ phosphate buffer, $\mathrm{pH} 7 \cdot 4$. Elution was at $18 \mathrm{ml} / \mathrm{h}$ flow rate; usually, $0.5-\mathrm{ml}$ fractions were collected and samples were assayed for enzymic activity.

\section{Enzymic activity assays}

The enzyme activity was monitored by a fluorogenic method with the AMC substrates. Ten $\mu$ l of freshly prepared yeast extracts or of each fraction from the enzyme purification steps were incubated with $20 \mu \mathrm{M}$ of fluorogenic substrate in $50 \mathrm{~mm}$ TBS, $\mathrm{pH} 7 \cdot 2$, to a final volume of $200 \mu \mathrm{l}$. After incubation for $15 \mathrm{~min}$ at $37^{\circ} \mathrm{C}$, the reaction was stopped by adding $1 \mathrm{ml}$ of ethanol. The fluorescence was measured at $440 \mathrm{~nm}$ with excitation at $380 \mathrm{~nm}$ for AMC. ${ }^{14}$ One $\mathrm{U}$ of L-Arg-
AMC activity was the amount catalysing hydrolysis and releasing $1.0 \mu \mathrm{mol}$ of $\mathrm{AMC} / \mathrm{min}$.

The effect of $\mathrm{pH}$ on enzyme activity was studied with the purified enzyme and the following buffers: $50 \mathrm{~mm}$ sodium acetate, $50 \mathrm{~mm}$ Tris- $\mathrm{HCl}$ or $50 \mathrm{~mm}$ carbonatebicarbonate with $0.15 \mathrm{M} \mathrm{NaCl}$ adjusted to the appropriate $\mathrm{pH}$ value from 4 to 10 .

For protease inhibitor assays, $10 \mu 1$ of enzyme solutions were pre-incubated at room temperature for $15 \mathrm{~min}$ with inhibitor before the addition of substrate. Controls were done under the same conditions but without protease inhibitors.

\section{Determination of $p I$}

For chromatofocusing, $1 \mathrm{ml}$ of cytoplasmic yeast extract in starting buffer $(25 \mathrm{~mm}$ imidazole- $\mathrm{HCl}$, pH 6.6) was injected into a Mono P column HR $5 \times 20$ previously equilibrated with the same buffer. Proteins were eluted at a flow rate of $30 \mathrm{ml} / \mathrm{h}$ with a linear pH 6.6-2.7 gradient established with $30 \mathrm{ml}$ of $1 / 8$ polybuffer 74, pH 2.7. Each 1-ml fraction, neutralised with one volume of $250 \mathrm{~mm}$ Tris- $\mathrm{HCl}, \mathrm{pH} 7 \cdot 2$, was assayed with L-Arg-AMC.

\section{Polyacrylamide gel electrophoresis}

Samples of purified enzyme fractions were dissolved in SDS $2 \%, \beta$-mercapto-ethanol $2 \%$ solution, boiled for $5 \mathrm{~min}$ and analysed by SDS-PAGE as described by Laemmli. ${ }^{15}$ The acrylamide concentrations in stacking and separating gels were $3 \%$ and $10 \%$, respectively. Gels were stained by the silver nitrate procedure according to Merril et al. ${ }^{16}$

\section{Visualisation of the proteolytic activity on polyacrylamide gel electrophoresis}

AMC-substrate was added to the separating gel mixture to a concentration of $1 \mathrm{mg} / \mathrm{ml}$ before polymerisation. Pre-stained mol. wt markers were boiled and run on each gel as a guide to apparent molecular masses. However, samples containing enzyme were not heated. SDS-PAGE was performed at $4^{\circ} \mathrm{C}$ at $15 \mathrm{~mA}$. To re-nature the enzyme, the gels were first rinsed briefly in de-ionised water and washed four times in Triton X-100 $0.1 \%$ for $30 \mathrm{~min}$ at $4^{\circ} \mathrm{C}$, then incubated at $37^{\circ} \mathrm{C}$ for $30 \mathrm{~min}$ in $50 \mathrm{~mm}$ TBS, pH 7.2. Enzyme activity was seen as fluorescent blue bands under long wave-length UV light. ${ }^{17}$

\section{Detection of proteolytic activity in native gel electrophoresis}

Samples of protein solution were mixed with an equal volume of sucrose and bromophenol blue and electrophoresed without prior heating in acrylamide $10 \% \mathrm{w} / \mathrm{v} /$ bisacrylamide $0.8 \% \mathrm{w} / \mathrm{v}$ gels. ${ }^{18}$

For enzyme detection, the gel was sliced into 2.5 mm horizontal strips. Each strip was then incubated at $37^{\circ} \mathrm{C}$ in $20 \mu \mathrm{m}$ AMC-substrate in $50 \mathrm{~mm}$ TBS, $\mathrm{pH} 7 \cdot 2$, 
for $1 \mathrm{~h}$ at $37^{\circ} \mathrm{C}$. Absorbance was read at $440 \mathrm{~nm}$ with excitation at $380 \mathrm{~nm}$ and bands of peptidase activity were detected as absorbance peaks due to the production of AMC.

\section{Results}

With 7-AMC-derivatives, the cytosoluble extract of C. albicans was found to contain an active enzyme that had the properties of an aminopeptidase. This enzyme was purified by HPLC. Fig. 1 shows the protein activity profile for the purification of this aminopeptidase on a Fractogel EMD-TMAE 650, an anionexchange chromatography column.

The active fraction from purification on the anionexchange chromatography column was concentrated by centricon membrane and then applied to the gel filtration column TSK G3000 $\mathrm{SW} \times \mathrm{L}$ at $\mathrm{pH} 7 \cdot 2$. Activity monitored with L-Arg-AMC appeared as a sharp symmetrical peak (fig. 2). Thus the two chromatography columns allowed a rapid 20 -fold total purification with high recovery of activity (table I). This purified peptidase had an optimal activity at $\mathrm{pH} 7.2$ with L-Arg-AMC as substrate, similar to the crude enzyme extract (fig. 3).

Analysis of the purified protein by SDS-PAGE on $10 \%$ gels gave a single protein band with an $M_{r}$ of $52 \mathrm{kDa}$ (fig. 4, lane A). This result was confirmed by native polyacrylamide gel electrophoresis. The gels were sliced and incubated with L-Arg-AMC substrate as described in Materials and methods. A single 52$\mathrm{kDa}$ band that hydrolysed L-Arg-AMC was revealed (data not shown). Furthermore, analysis of the purified protein or the cytoplasmic extract gave a single blue band due to release of 7-AMC when they were electrophoresed in a polyacrylamide $10 \%$ gel containing L-Arg-AMC (fig. 4, lanes B and C). This result indicated an $M_{r}$ of $52 \mathrm{kDa}$, which agreed with its elution in the void volume of the TSK G3000 SW $\times \mathrm{L}$ column.

\section{Determination of $p I$}

Chromatofocusing on a Mono $\mathrm{P}$ column was used to determine the iso-electric point. When the C. albicans extract was subjected to a linear 6.6-2.7 $\mathrm{pH}$ gradient, the L-Arg-AMC peptidase was detected as a single peak of activity in the acidic fraction at $c . \mathrm{pH} 4 \cdot 2$ (fig. 5).

\section{Inhibition sensitivity}

The effects of various inhibitors on peptidase activity were determined (table II). $O$-Phenanthroline and EDTA, potent inhibitors of metallopeptidase, completely blocked enzyme activity. However, phosphoramidon-which is also a metallo-enzyme inhibitor-did not inhibit this activity at a concentration of $0.5 \mathrm{~mm}$. Metals with a high affinity for

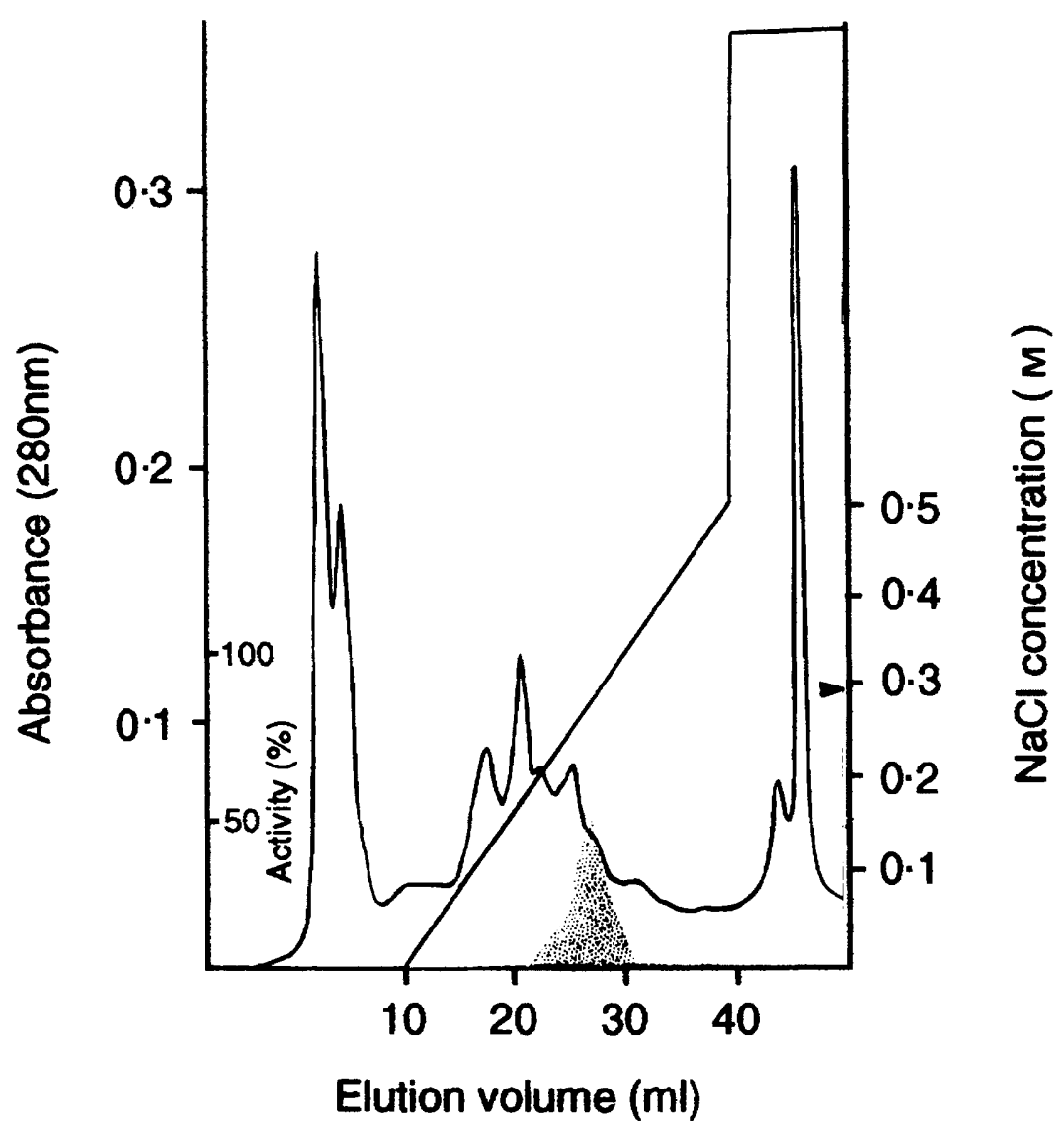

Fig. 1. Fractogel EMD-TMAE 650 ion-exchange chromatography of $100000 \mathrm{~g}$ C. albicans extract. A 30 -ml linear gradient of $25 \mathrm{~mm}$ Tris- $\mathrm{HCl}$, $\mathrm{pH} 7 \cdot 4$, with $0-0.5 \mathrm{M} \mathrm{NaCl}$ was used for this purification step. The flow rate was $30 \mathrm{ml} / \mathrm{h}$ and samples of each $1 \cdot 0-\mathrm{ml}$ fraction were assayed for enzymic activity (周). 


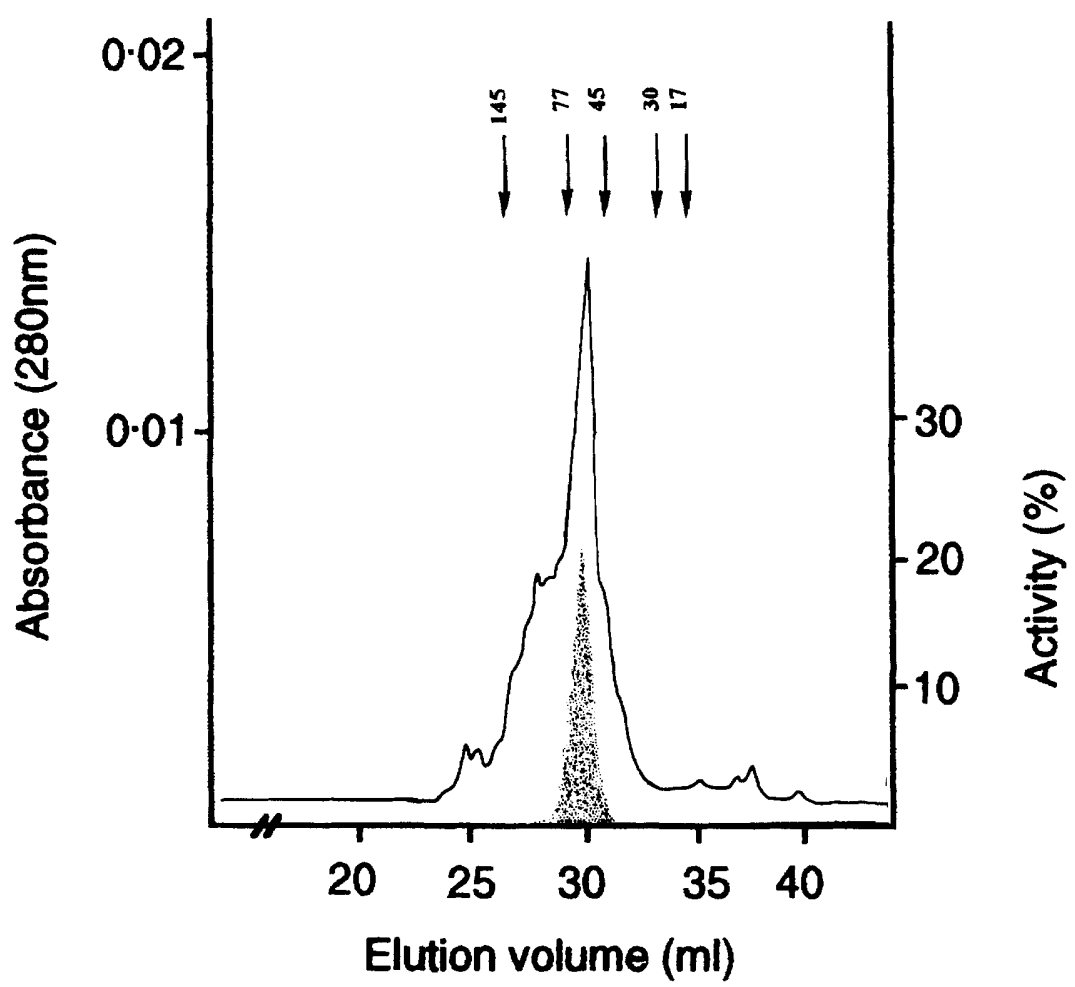

Fig. 2. After a first fractogel EMD-TMAE 650 ion-exchange chromatography, the pooled active fractions were injected into a gel filtration TSK G3000 SW $\times \mathrm{L}$ column. The flow rate was $18 \mathrm{ml} / \mathrm{h}$ and samples of each fraction were assayed for activity with $20 \mu \mathrm{M} \mathrm{L}-\mathrm{Arg}-\mathrm{AMC}$ as substrate (圈). Calibration standards (arrows) were: lactate dehydrogenase, $145 \mathrm{kDa}$; ovotransferrin, $77 \mathrm{kDa}$; ovalbumin, $45 \mathrm{kDa}$; carbonic anhydrase, $30 \mathrm{kDa}$; myoglobin, $17 \mathrm{kDa}$.

Table I. Purification of $C$. albicans metallopeptidase

\begin{tabular}{lcccccc}
\hline Purification step & $\begin{array}{c}\text { Volume } \\
(\mathrm{ml})\end{array}$ & $\begin{array}{c}\text { Protein } \\
(\mathrm{mg} / \mathrm{ml})\end{array}$ & $\begin{array}{c}\text { Specific activity } \\
(\mathrm{U} / \mathrm{mg})\end{array}$ & $\begin{array}{c}\text { Total activity } \\
(\mathrm{U})\end{array}$ & $\begin{array}{c}\text { Purification } \\
\text { factor }\end{array}$ & $\begin{array}{c}\text { Recovery } \\
(\%)\end{array}$ \\
\hline Cell extract & 1 & $4 \cdot 5$ & $437 \cdot 3$ & $1967 \cdot 8$ & $\ldots$ & 100 \\
Fractogel EMD-TMAE & 0.5 & $0 \cdot 46$ & $2029 \cdot 85$ & $466 \cdot 86$ & $4 \cdot 6$ & $23 \cdot 7$ \\
TSK G3000 & 0.5 & 0.025 & $15903 \cdot 6$ & $397 \cdot 59$ & $36 \cdot 3$ & $20 \cdot 2$ \\
\hline
\end{tabular}

The purification started with $1 \mathrm{ml}$ of cell-free extract (100000 $\mathrm{g}$ supernate). The enzyme activity was determined at $37^{\circ} \mathrm{C}$ with L-Arg-AMC as substrate.

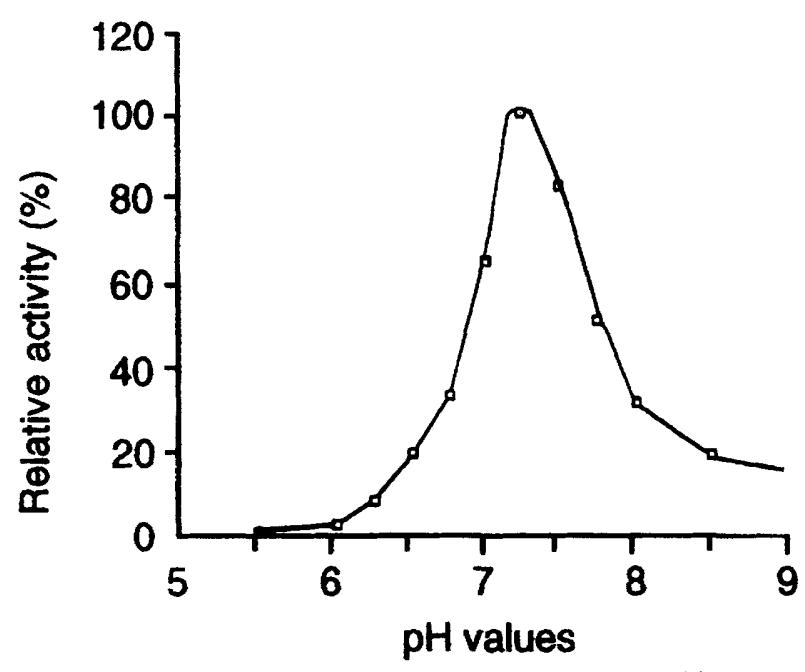

Fig. 3. Effect of $\mathrm{pH}$ on activity of $C$. albicans aminopeptidase. The maximal activity observed was set as $100 \%$ relative enzyme activity. Enzyme assays were performed with $20 \mu \mathrm{M}$ of L-Arg-AMC in buffers at different $\mathrm{pH}$ values as described in Materials and methods.

sulphydryl groups, such as $\mathrm{Hg}^{2+}$ and $\mathrm{Zn}^{2+}$, inactivated the enzyme readily. Other sulphydryl reagents, such as iodoacetamide or $N$-ethylmaleimide, did not inactivate the enzyme under the conditions used in these studies. Dithiothreitol, a reductive splitter of disulphide linkages, had a low inhibitory effect. Aminopeptidase activity was not inhibited by the serine protease inhibitor PMSF or by the chymotrypsin inhibitor TLCK.

\section{Substrate specificity}

In addition to L-Arg-AMC, the purified $C$. albicans 2091 metallopeptidase was able to cleave L-Leu-AMC. These substrates gave specific activities of 418 and $290 \mu \mathrm{mol} \mathrm{AMC} \mathrm{released} / \mathrm{min} / \mathrm{mg}$ of protein, respectively by spectrofluorometry (table III).

\section{Aminopeptidase activity in other Candida species}

Three $C$. albicans strains isolated from urine, vagina and mouth, and $C$. tropicalis, $C$. glabrata, C. parapsilosis, C. krusei, C. guilliermondi and C. pseudotropicalis were examined for the expression of aminopeptidase activity (table IV). All these yeasts 


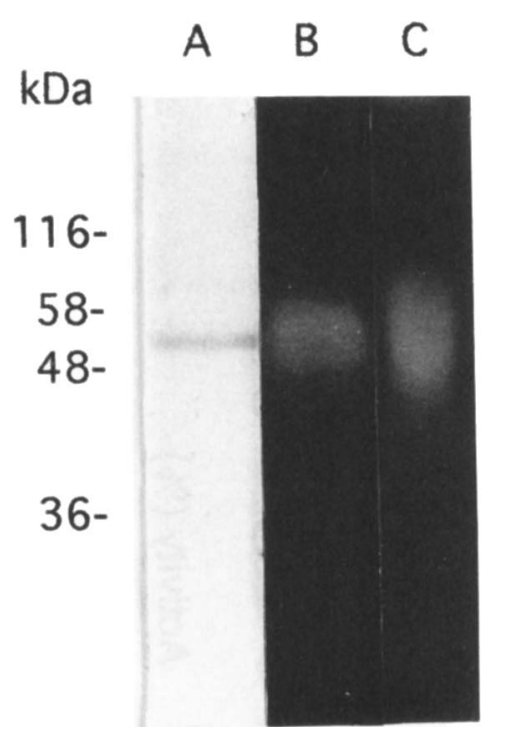

Fig. 4. SDS-PAGE analysis of the enzyme fraction after the two-step purification procedure described in figs. 1 and 2 . The electrophoresis was done under reducing conditions. Numbers on the left are calibration standards: $\beta$-galactosidase, $116 \mathrm{kDa}$; pyruvate kinase, $58 \mathrm{kDa}$; fumarase, $48 \mathrm{kDa}$; lactic dehydrogenase, $36 \mathrm{kDa}$; lane $\mathrm{A}$ purified enzyme stained by the silver procedure; $B$ and $\mathbf{C}$, blue AMC colour bands produced when the purified enzyme or crude extract, respectively, were electrophoresed in acrylamide gel containing L-Arg-AMC as substrate.

expressed a peptidase activity in their cytoplasmic extract that cleaved L-Arg-AMC with a $\mathrm{pH}$ optimum of 7.2. Furthermore, the peptidase activity in these species and in clinical isolates of $C$. albicans had the same inhibitor sensitivity as the C. albicans 2091 metallopeptidase. Therefore, extracts of all isolates tested contained an aminopeptidase that resembled the $C$. albicans 2091 enzyme.
Table II. Effects of various inhibitors on the purified C. albicans metallopeptidase activity at $\mathrm{pH} 7 \cdot 2$

\begin{tabular}{lcc}
\hline Compound & Final concentration & Percentage inhibition \\
\hline Control & $1 \mathrm{mM}$ & 0 \\
$\mathrm{CaCl}_{2}$ & $1 \mathrm{~mm}$ & 34 \\
$\mathrm{MnCl}_{2}$ & $1 \mathrm{mM}$ & 5 \\
$\mathrm{HgCl}_{2}$ & $1 \mathrm{mM}$ & 95 \\
$\mathrm{ZnCl}_{2}$ & $1 \mathrm{mM}$ & 82 \\
EDTA & $1 \mathrm{mM}$ & 93 \\
Iodoacetamide & $1 \mathrm{~mm}$ & 29 \\
DTT & $1 \mathrm{mM}$ & 38 \\
$o$-Phenanthroline & $1 \mathrm{mM}$ & 93 \\
PMSF & $1 \mathrm{mM}$ & 0 \\
NEM & $0 \cdot 5 \mathrm{mM}$ & 0 \\
Phosphoramidon & $1 \mathrm{mM}$ & 0 \\
TLCK & $10 \mu \mathrm{M}$ & 23 \\
E64 & & 20 \\
& & \\
\hline
\end{tabular}

\section{Discussion}

In the present work, aminopeptidase activity was identified in $C$. albicans by a highly sensitive method with L-Arg and L-Leu 7-amino-4-methylcoumarin as substrates. The activity of enzyme in $C$. albicans cell lysates was 418 and $290 \mathrm{U} / \mathrm{mg}$ protein for L-ArgAMC and L-Leu-AMC respectively. The purified peptidase showed optimum activity at $\mathrm{pH} 7.2$ and an iso-electric point of $4 \cdot 2$, a $\mathrm{Km}$ of $50 \mu \mathrm{M}$ and a $\mathrm{V}_{\max }$ at $19 \mathrm{mM}$ AMC released $/ \mathrm{min} / \mathrm{mg}$ of protein for L-Arg-AMC.

Anion-exchange chromatography and gel filtration of the C. albicans extract yielded a purification of 36fold and indicated a single protein of $52 \mathrm{kDa}$. This result was confirmed by native SDS-PAGE or gelenzymography with L-Arg-AMC as substrate co-

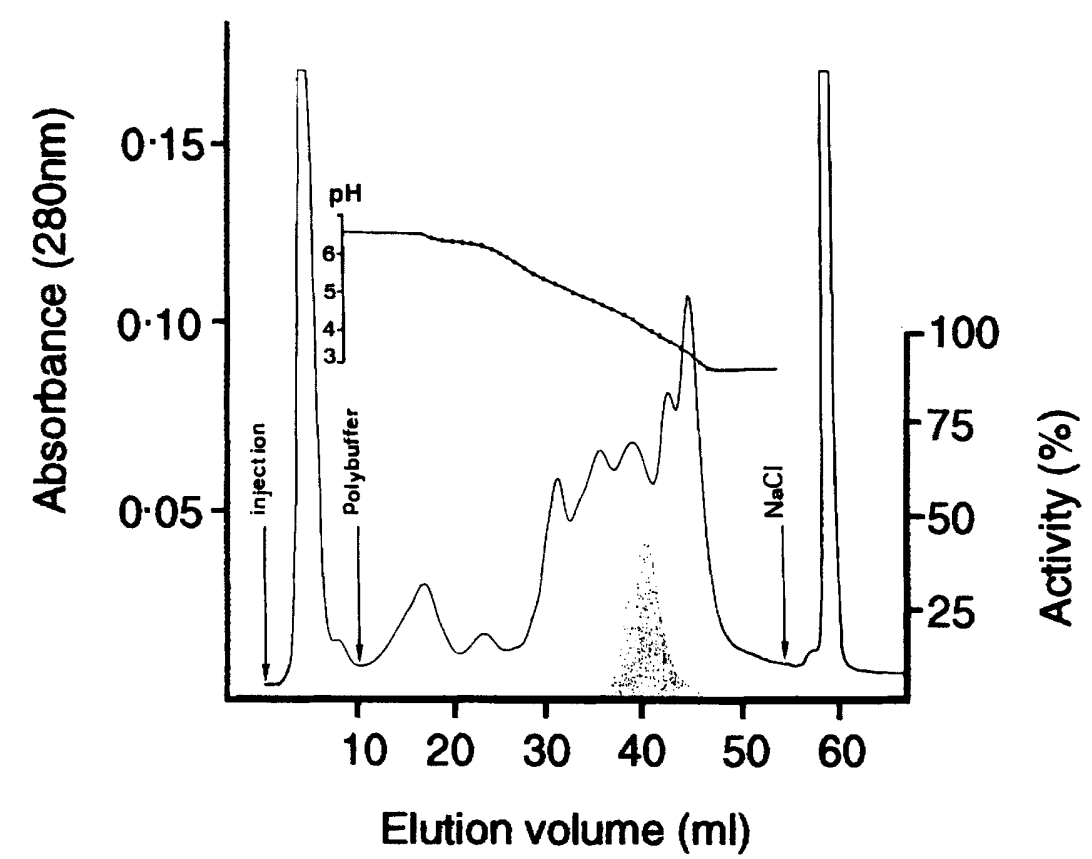

Fig. 5. Chromatofocusing on Mono P column of a $100000 \mathrm{~g}$ C. albicans extract in 25 mm imidazole buffer, pH 6.6 . Elution formation of a pH 6.6-2.7 gradient with $45 \mathrm{ml}$ of polybuffer $/ \mathrm{HCl}, \mathrm{pH} 2 \cdot 7$; flow rate: $30 \mathrm{ml} / \mathrm{min}$. Fractions were monitored for protein content at $280 \mathrm{~nm}$ and $10-\mu \mathrm{l}$ samples of each fraction were assayed for activity with L-Arg-AMC, the hatched area corresponds to the active fraction. 
Table III. Rates of hydrolysis of various 7-AMC substrates ( $20 \mu \mathrm{M}$ final concentration) by purified metallopeptidase of C. albicans

\begin{tabular}{|c|c|}
\hline Substrate & $\begin{array}{c}\text { Rate of hydrolysis } \\
\text { ( } \mu \mathrm{mol} \text { AMC released } / \mathrm{min} / \mathrm{mg} \text { of } \\
\text { protein })\end{array}$ \\
\hline L-Arg-AMC & 418 \\
\hline L-Leu-AMC & 290 \\
\hline L-Lys-AMC & $42 \cdot 2$ \\
\hline L-Tyr-AMC & 15 \\
\hline D-Ala-Leu-Lys-AMC & \multirow{9}{*}{ No detectable activity } \\
\hline $\begin{array}{l}N \text {-t-BOC- } \beta \text {-Benzyl-Asp- } \\
\text { Pro-Arg-AMC }\end{array}$ & \\
\hline $\begin{array}{l}N \text {-Methoxysuccinyl-Ala- } \\
\text { Ala-Pro-Val-AMC }\end{array}$ & \\
\hline $\begin{array}{l}N \text {-Succinyl-Leu-Leu-Val- } \\
\text { Tyr-AMC }\end{array}$ & \\
\hline Lys-Ala-AMC & \\
\hline $\begin{array}{l}N \text {-Succinyl-Ala-Ala-Ala- } \\
\text { AMC }\end{array}$ & \\
\hline $\begin{array}{l}N \text {-Succinyl-Ala-Ala-Phe- } \\
\text { AMC }\end{array}$ & \\
\hline $\begin{array}{l}\text { N-CBZ-Gly-Gly-Arg- } \\
\text { AMC }\end{array}$ & \\
\hline $\begin{array}{l}N \text {-Succinyl-Gly-Pro-Leu- } \\
\text { Gly-Pro-AMC }\end{array}$ & \\
\hline
\end{tabular}

Table IV. Rate of hydrolysis of L-Arg-AMC substrate $(20 \mu \mathrm{M}$ final concentration) by cytoplasmic extract of various C. albicans isolates and other Candida spp.

\begin{tabular}{lc} 
Test strain & $\begin{array}{c}\text { Rate of hydrolysis } \\
(\mu \mathrm{mol} \text { AMC released/min/mg of protein })\end{array}$ \\
\hline C. albicans 2091 & 390 \\
Isolate from vagina & 205 \\
Isolate from urine & 328 \\
Isolate from mouth & 347 \\
C. glabrata & $84 \cdot 2$ \\
C. tropicalis & 106 \\
C. parapsilosis & 124 \\
C. krusei & 276 \\
C. yuilliermondi & 330 \\
C. pseudotropicalis & 306 \\
\hline
\end{tabular}

polymerised with acrylamide. These procedures enabled the $M_{r}$ of the aminopeptidase to be determined. However, this enzyme failed to cleave gelatin co-polymerised in SDS-PAGE, in contrast with the two serine proteinases of $C$. albicans with $M_{r} 50000$ and $M_{r} 60000 .{ }^{12}$ This result shows that this enzyme has a narrow specificity for short peptides.

\section{References}

1. Calderone RA. Host-parasite relationships in candidosis. Mycoses 1989; 32 Suppl 2: 12-17.

2. Rüchel R, de Bernardis F, Ray TL, Sullivan PA, Cole GT. Candida acid proteinases. J Med Vet Mycol 1992; 30 Suppl $1: 123-132$

3. Chattaway FW, Odds FC, Barlow AJE. An examination of the production of hydrolytic enzymes and toxins by pathogenic strains of Candida albicans. J Gen Microbiol 1971; 67: $255-263$.
The lack of inhibition by NEM and iodoacetamide excluded the enzyme from the cysteine proteinase class (EC 3.4.22). PMSF had no effect on the activity, excluding it from the serine proteinase class (EC 3.4.21). However, since $1 \mathrm{~mm} o$-phenanthroline and $1 \mathrm{~mm}$ EDTA completely blocked the enzyme activity, it is likely that this peptidase is a member of the metallo-enzyme class (EC 3.4.24). The optimum activity at $\mathrm{pH} 7 \cdot 2$ and the decreased activity with $\mathrm{Zn}^{2+}$ were in agreement with the known slightly alkaline $\mathrm{pH}$ optimum of metalloproteinases. Metalloproteinases contain zinc, and additional $\mathrm{Zn}^{2+}$ in the assay medium usually does not increase activity but may decrease it. ${ }^{19}$

Different proteases had been described in C. albicans with albumin, keratin or fluorogenic peptides as substrates. Among them, Rüchel ${ }^{2,4}$ has purified an extracellular acid proteinase-first reported by Staib $^{20}$ — with BSA as nitrogen source. This enzyme has a mol. wt of 42000 , an iso-electric point of $4 \cdot 5$, an optimum activity at $\mathrm{pH} 4$ and is inhibited by pepstatin and chymostatin. ${ }^{4}$ Several intracellular proteinases of C. albicans have been identified and characterised with peptide substrates. ${ }^{6,9,12,23}$ The properties of the present metallo-enzyme acting at neutral $\mathrm{pH}$ differ from those of the acid or neutral yeast proteinase described in $C$. albicans. This aminopeptidase differs from the metal ion-dependent aminopeptidases described by Logan et al. ${ }^{12}$ and Portillo and Gancedo. ${ }^{21}$ These enzymes present a much higher mol. wt (243000 and 67000 respectively) than that reported here for the C. albicans enzyme.

Our data demonstrate the existence of an aminopeptidase in C. albicans and similar activity in other Candida spp. The occurrence of a peptidase activity in all Candida strains tested having a $\mathrm{pH}$ optimum of $7 \cdot 2$, similar inhibitor sensitivity and similar substrate specificity provides evidence that this peptidase could be a major enzyme in all Candida strains.

The biological function of the metallopeptidase described in this paper remains to be determined. Its optimal activity was at $\mathrm{pH} 7 \cdot 2$ and it will be of interest to determine if the present aminopeptidase is directly involved in the mechanism of tissue invasion by C. albicans. This enzyme could be a new target for the development of anti-fungal peptidyl drug strategy based on peptidase inhibitors.

We thank Mr A. Gorenflot and D. Rigomier for helpful discussion. This work was partly supported by the "Conseil Regional Poitou-Charentes".

4. Rüchel R. Properties of a purified proteinase from the yeast Candida albicans. Biochim Biophys Acta 1981 ; 659: 99-113.

5. Logan DA, Naider F, Becker JM. Peptidases of yeast and filamentous forms of Candida albicans. Exp Mycol 1983: 7: $116-126$.

6. Negi M, Tsuboi R, Matsui T, Ogawa $H$. Isolation and characterization of proteinase from Candida albicans: substrate specificity. $J$ Invest Dermatol $1984 ; 83: 32-36$.

7. Hattori M, Yoshiura K, Negi M, Ogawa $H$. Keratinolytic proteinase produced by Candida albicans. Sabouraudia 1984; 22 : 175-183. 
8. Logan DA. Neutral proteinase activity of Candida albicans. Exp Mycol 1986; 10: 157-160.

9. Farley PC, Shepherd MG, Sullivan PA. The purification and properties of yeast proteinase B from Candida albicans. Biochem J 1986; 236: 177-184.

10. Ray TL, Payne CD, Morrow BJ. Candida albicans acid proteinase: characterization and role in candidiasis. $A d v$ Exp Med Biol 1991; 306: 173-183.

11. Logan DA. Partial purification and characterization of intracellular carboxypeptidase of Candida albicans. Exp Mycol 1987; 11: 115-121.

12. Rodier MH, El Moudni B, Ghazali M, Lacroix C, Jacquemin JL. Electrophoretic detection of cytoplasmic serine proteinases (gelatinases) in Candida albicans. Exp Mycol 1994; 18: 267-270.

13. Bradford MM. A rapid and sensitive method for the quantitation of microgram quantities of protein utilizing the principle of protein-dye binding. Anal Biochem 1976; 72: 248-254.

14. Zimmerman M, Ashe B, Yurewicz E, Patel G. Sensitive assays for trypsin, elastase, and chymotrypsin using new fluorogenic substrates. Anal Biochem 1977; 78: 47-51.

15. Laemmli UK. Cleavage of structural proteins during the assembly of the head of bacteriophage T4. Nature 1970; 227: $680-685$.

16. Merril CR, Goldman D, Sedman SA, Ebert MH. Ultrasensitive stain for proteins in polyacrylamide gels shows regional variation in cerebrospinal fluid proteins. Science $1981 ; 211$ : $1437-1438$.

17. Lincoln SP, Fermor TR, Wood DA. A novel method for detecting acetylglucosaminidase activity on polyacrylamide gels. J Microbiology Methods 1994; 20 : 79-85.

18. Strongin AY, Azarenkova NM, Vaganova TI, Levin ED, Stepanov VM. Visualization of leucineaminopeptidase activity after acrylamide gel electrophoresis. Anal Biochem 1976; 74 : $597-599$.

19. Barrett AJ. An introduction to the proteinases. In: Barrett AJ, Salvesen G (eds) Proteinase inhibitors (Research monographs in cell and tissue physiology, vol 12). Amsterdam, Elsevier/North-Holland Biomedical Press. 1986: 3-22.

20. Staib F. Serum-proteins as nitrogen source for yeastlike fungi. Sabouroudia 1965; 4: 187-193.

21. Portillo F, Gancedo C. Purification and properties of three intracellular proteinases from Candida albicans. Biochim Biophys Acta 1986; 881 : 229-235. 